\title{
Bronchial atresia: a rare presentation as air fluid level on chest roentgenogram
}

\author{
Hameed Aboobackar Shahul, ${ }^{1}$ Mohan K Manu, ${ }^{1}$ Aswini Kumar Mohapatra, ${ }^{1}$ \\ Charudutt Jayant Sambhaji ${ }^{2}$
}

'Department of Pulmonary Medicine, Kasturba Medical College, Manipal, Karnataka, India

${ }^{2}$ Department of Radiodiagnosis and Imaging, Kasturba Medical College Manipal, Manipal, Karnataka, India

\section{Correspondence to} Dr Mohan K Manu, manumohan73@gmail.com

\section{DESCRIPTION}

A 48-year-old man, non-smoker, was admitted for evaluation of his abnormal chest roentgenogram, which showed a left mid and lower zone cavity with air fluid level (figure 1). There was no history of fever, haemoptysis, chest pain or constitutional symptoms. The history was insignificant except for bronchial asthma which was under control.

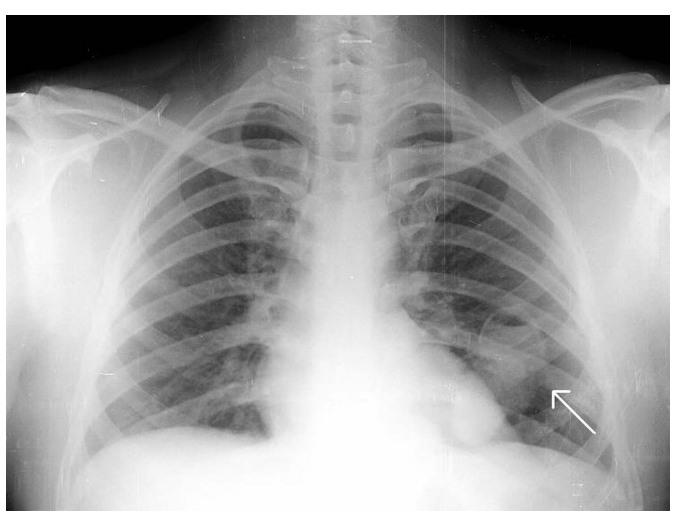

Figure 1 Chest X-ray showing a left mid and lower zone cavity with air fluid level (white arrow).
General physical and systemic examination was essentially normal. Routine blood investigations were unremarkable. Sputum Gram staining, Ziehl-Neelsen staining for mycobacteria and bacterial culture were normal. A contrast-enhanced CT (CECT) thorax (figure 2A,B) showed a rounded, tubular, hypodense lesion located in the posterior basal segment of the left lower lobe with peripheral calcification suggestive of mucoid impaction and a similar nodule in the subpleural segment of the left lower lobe. The lesions were non-enhancing and had a typical branching character with decreased attenuation of surrounding lung parenchyma in the posterior basal segments suggestive of air trapping. These features were consistent with bronchial atresia. The patient was advised for regular follow-up in view of possible infections and progression.

Bronchial atresia is characterised by a central, atretic bronchus leading to mucus impaction and bronchocoele formation. ${ }^{1}$ It is usually detected in asymptomatic individuals as an incidental radiographic finding - a branching opacity radiating from the hilum, surrounded by an area of hyperlucency. ${ }^{2}$ Rarely, as in this case, it may present as an air fluid level on chest radiograph. ${ }^{3}$
To cite: Shahul HA, Manu MK, Mohapatra AK, et al. BMJ Case Rep Published online: [please include Day Month Year] doi:10.1136/bcr-2013202767

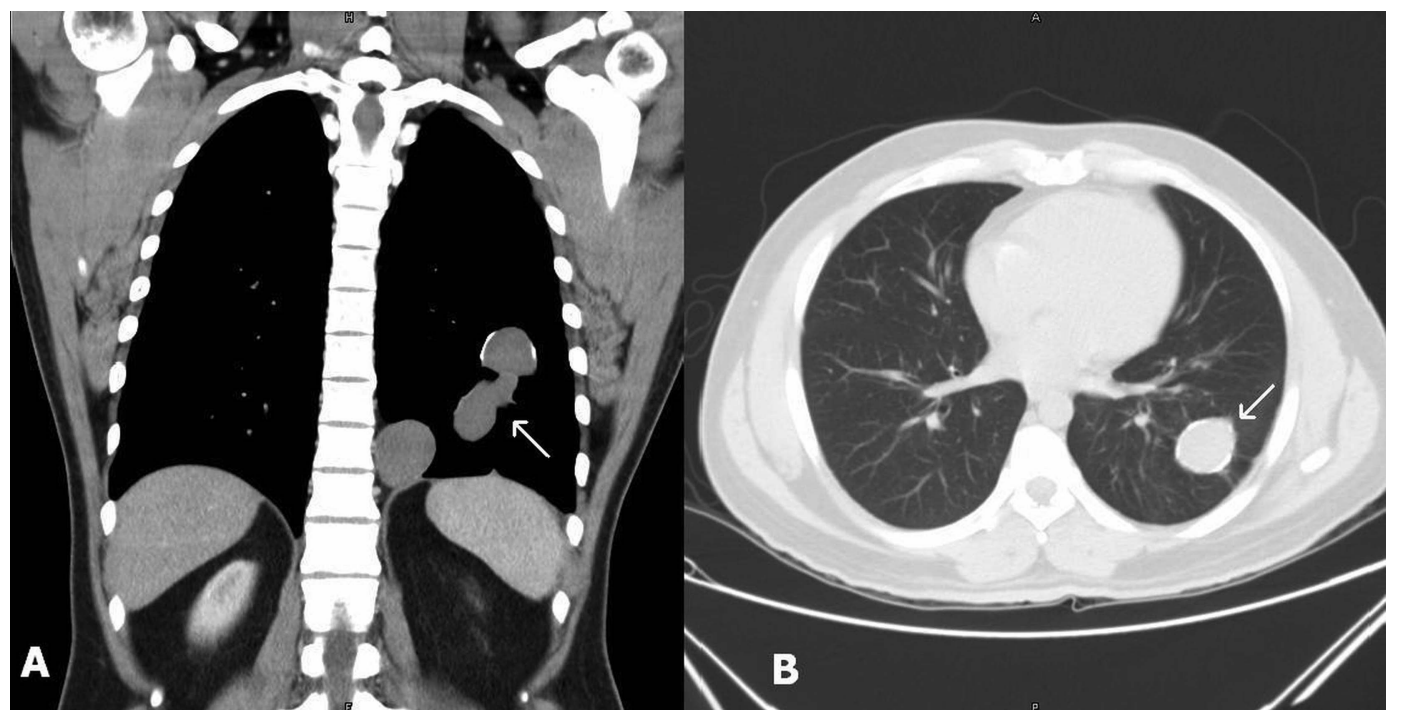

Figure 2 Contrast-enhanced CT of the thorax ((A) coronal view and (B) axial view) showing a rounded, tubular, hypodense lesion in the posterior basal segment of the left lower lobe with peripheral calcification and a similar nodule in the subpleural segment of the left lower lobe, both of which are non-enhancing and with typical branching character, with decreased attenuation of surrounding lung parenchyma (white arrows). 


\section{Learning points}

- A variety of pathological conditions such as cavitary lung lesions and loculated empyema can present as an air fluid level on chest radiograph.

- Bronchial atresia typically presents as a branching opacity radiating from the hilum surrounded by an area of hyperlucency or as air fluid level, though rarely, on chest radiograph.

- A CT of the thorax is diagnostic of bronchial atresia and recognition of $\mathrm{CT}$ features helps in avoiding further investigations and poor management decisions.
Competing interests None.

Patient consent Obtained.

Provenance and peer review Not commissioned; externally peer reviewed.

\section{REFERENCES}

1 Ramsay BH. Mucocele of the lung due to congenital obstruction of a segmental bronchus: a case report-relationship to congenital cystic disease of the lung and to congenital bronchiectasis. Dis Chest 1953;24:96-103.

2 Cohen AM, Solomon EH, Alfidi RJ. Computed tomography in bronchial atresia. AJR Am J Roentgenol 1980;135:1097-9.

3 Berrocal T, Madrid C, Novo S, et al. Congenital anomalies of the tracheobronchial tree, lung, and mediastinum: embryology, radiology, and pathology. Radiographics 2004;24:e17.

Copyright 2014 BMJ Publishing Group. All rights reserved. For permission to reuse any of this content visit http://group.bmj.com/group/rights-licensing/permissions.

BMJ Case Report Fellows may re-use this article for personal use and teaching without any further permission.

Become a Fellow of BMJ Case Reports today and you can:

- Submit as many cases as you like

- Enjoy fast sympathetic peer review and rapid publication of accepted articles

- Access all the published articles

- Re-use any of the published material for personal use and teaching without further permission

For information on Institutional Fellowships contact consortiasales@bmjgroup.com

Visit casereports.bmj.com for more articles like this and to become a Fellow 